showed hypoperfusion in the right frontal-central area. Carbamazepine treatment had completely controlled seizures at 22 month follow-up. (Pierelli F, Di Gennaro G. Gherardi M, Spanedda F, Marciani MG. Epilepsia Aug 1997;38:941-944). (Reprints: Dr F Pierelli, Instituto di Clinica delle Malattie Nervose e Mentali, Viale dell'Universita 30, 00185, Rome, Italy).

COMMENT. Reflex seizures induced by movement have been reported previously, sometimes in patients with nonketotic hyperglycemia of diabetes mellitus.

\title{
AGE-DEPENDENT STATUS EPILEPTICUS
}

The records of 394 children aged 1 month to 16 years with status epilepticus (SE) were reviewed at the Montefiore Medical Center, Bronx, NY, and Medical College of Virginia, Richmond, VA. The mean age of onset was 4 years, and more than half the cases occurred under 3 years. Causes were agedependent. Febrile or acute symptomatic SE occurred at less than 2 years, whereas cryptogenic and remote symptomatic cases were common in older children. Prior neurologic abnormalities were noted in $40 \%$ ( $21 \%$ of younger and $55 \%$ of those older than 2 years), and a history of previous seizures in $45 \%$. The prevalence of previous seizures was significantly higher in older children; $64 \%$ in those older than 2 years and $20 \%$ in children less than 2 years. (Shinnar S, Pellock JM, Moshe SL et al. In whom does status epilepticus occur: Age-related differences in children. Epilepsia Aug 1997;38:907-914). (Reprints: Dr S Shinnar, Epilepsy Management Center, Montefiore Medical Center, $111 \mathrm{E}$ 210th St, Bronx, NY 10467).

COMMENT. Young children are particularly susceptible to status epilepticus, primarily those without neurologic abnormalities and with no previous unprovoked seizures. Older children with SE have a history of prior cryptogenic seizures, but are more frequently neurologically impaired.

\section{HERPES SIMPLEX VIRUS AND SURGICAL EPILEPSY}

The presence of herpes simplex virus (HSV) was determined by polymerase chain reaction in surgical specimens from 50 patients (13 to 58 years of age) with epilepsy obtained from multiple centers, including the National Neurological Research Specimen Bank, West Los Angeles Veterans Affairs Medical Center, Los Angeles, CA. Twenty (40\%) of the 50 epilepsy surgical cases and only $2(4 \%)$ of 48 control autopsy specimens from Alzheimer and Parkinson disease patients tested positive for HSV. Heterotopias were the most frequent epileptic tissue abnormalities (12 cases), and $67 \%$ tested positive for HIV. Of 8 with hippocampal sclerosis, $50 \%$ were HIV positive. (Sanders VJ, Felisan SL, Waddell AER et al. Presence of herpes simplex DNA in surgical tissue from human epileptic seizure foci detected by polymerase chain reaction. Arch Neurol Aug 1997;54:954-960). (Respond: Dr WW Tourtellotte, Neurology Services (127A), West Los Angeles VA Medical Center, 11301 Wilshire Blvd, Los Angeles, CA 90073).

COMMENT. Although this finding of herpes simplex virus in epileptogenic cerebral tissue does not prove a causative effect, the association is provocative and should stimulate research of possible viral etiology of refractory epilepsies in children, especially those with evidence of heterotopias, infantile spasms, complex febrile seizures, and perhaps, the Landau-Kleffner syndrome. A trial of acyclovir may be considered in some. 